ano 16 - n. 63। janeiro/março - 2016

Belo Horizonte I p. 1-262 I ISSN 1516-3210

A\&C - R. de Dir. Administrativo \& Constitucional

Revista de Direito ADMINISTRATIVO \& CONSTITUCIONAL

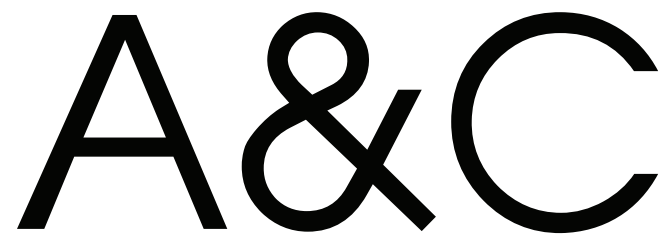




\section{A\&C - REVISTA DE DIREITO ADMINISTRATIVO \& CONSTITUCIONAL}

IPDA

Instituto Paranaense

de Direito Administrativo
ROMEU DELPE

BACELLAR

(c) 2016 Editora Fórum Ltda.

Todos os direitos reservados. É proibida a reprodução total ou parcial, de qualquer forma ou por qualquer meio eletrônico ou mecânico, inclusive através de processos xerográficos, de fotocópias ou de gravação, sem permissão por escrito do possuidor dos direitos de cópias (Lei no 9.610, de 19.02.1998).

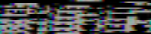

Luís Cláudio Rodrigues Ferreira

Presidente e Editor

Av. Afonso Pena, 2770 - 15a andar - Savassi - CEP 30130-012 - Belo Horizonte/MG - Brasil - Tel.: 08007043737 www.editoraforum.com.br / E-mail: editoraforum@editoraforum.com.br

Impressa no Brasil / Printed in Brazil / Distribuída em todo o Território Nacional

Os conceitos e opiniões expressas nos trabalhos assinados são de responsabilidade exclusiva de seus autores.

\begin{tabular}{|c|c|}
\hline A246 & $\begin{array}{l}\text { A\&C : Revista de Direito Administrativo \& } \\
\text { Constitucional. - ano 3, n. 11, (jan./mar. } \\
\text { 2003)- . - Belo Horizonte: Fórum, 2003- }\end{array}$ \\
\hline & 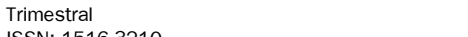 \\
\hline & $\begin{array}{l}\text { Ano 1, n. 1, } 1999 \text { até ano 2, n. 10, } 2002 \text { publicada } \\
\text { pela Editora Juruá em Curitiba }\end{array}$ \\
\hline & $\begin{array}{l}\text { 1. Direito administrativo. } 2 \text {. Direito constitucional. } \\
\text { I. Fórum. }\end{array}$ \\
\hline & $\begin{array}{l}\text { CDD: } 342 \\
\text { CDU: } 342.9\end{array}$ \\
\hline
\end{tabular}

Coordenação editorial: Leonardo Eustáquio Siqueira Araújo Capa: Igor Jamur

Projeto gráfico e diagramação: Walter Santos

\section{Periódico classificado no Estrato A1 do Sistema Qualis da CAPES - Área: Direito.}

Revista do Programa de Pós-graduação do Instituto de Direito Romeu Felipe Bacellar (Instituição de Pesquisa e Pós-Graduação), em convênio com o Instituto Paranaense de Direito Administrativo (entidade associativa de âmbito regional filiada ao Instituto Brasileiro de Direito Administrativo). A linha editorial da $A \& C$ - Revista de Direito Administrativo \& Constitucional segue as diretrizes do Programa de Pós-Graduação do Instituto de Direito Romeu Felipe Bacellar em convênio com o Instituto Paranaense de Direito Administrativo. Procura divulgar as pesquisas desenvolvidas na área de Direito Constitucional e de Direito Administrativo, com foco na questão da efetividade dos seus institutos não só no Brasil como no direito comparado, com ênfase na questão da interação e efetividade dos seus institutos, notadamente América Latina e países europeus de cultura latina.

A publicação é decidida com base em pareceres, respeitando-se o anonimato tanto do autor quanto dos pareceristas (sistema double-blind peer review).

Desde o primeiro número da Revista, $75 \%$ dos artigos publicados (por volume anual) são de autores vinculados a pelo menos cinco instituições distintas do Instituto de Direito Romeu Felipe Bacellar.

A partir do volume referente ao ano de 2008 , pelo menos $15 \%$ dos artigos publicados são de autores filiados a instituições estrangeiras.

Esta publicação está catalogada em:

- Ulrich's Periodicals Directory

- RVBI (Rede Virtual de Bibliotecas - Congresso Nacional)

- Library of Congress (Biblioteca do Congresso dos EUA)

A\&C - Revista de Direito Administrativo \& Constitucional realiza permuta com as seguintes publicações: - Revista da Faculdade de Direito, Universidade de São Paulo (USP), ISSN 0303-9838

- Rivista Diritto Pubblico Comparato ed Europeo, ISBN/EAN 978-88-348-9934-2 
Diretor-Geral

Romeu Felipe Bacellar Filho

Diretor Editorial

Paulo Roberto Ferreira Motta

Editores Acadêmicos Responsáveis

Daniel Wunder Hachem

Ana Cláudia Finger

Assessor Editorial

Felipe Klein Gussoli

\section{Conselho Editorial}

Adilson Abreu Dallari (PUC-SP) Juan Pablo Cajarville Peluffo (Universidad de La República - Uruguai) ardo Schier (Instituto Bacellar) Justo J. Reyna (Universidad Nacional del Litoral - Argentina)

Alice Gonzalez Borges (UFBA) Juarez Freitas (UFRGS)

Carlos Ari Sundfeld (FGV-SP) Luís Enrique Chase Plate (Universidad Nacional de Asunción - Paraguai)

Carlos Ayres Britto (UFSE) Marçal Justen Filho (UFPR)

Adriana da Costa Ricardo Schier (Instituto Bacellar)
Alice Gonzalez Borges (UFBA)

Marcelo Figueiredo (PUC-SP)

Márcio Cammarosano (PUC-SP)

Carlos Delpiazzo (Universidad de La República - Uruguai) Cármen Lúcia Antunes Rocha (PUC Minas) Célio Heitor Guimarães (Instituto Bacellar) Celso Antônio Bandeira de Mello (PUC-SP) Clèmerson Merlin Clève (UFPR) Clovis Beznos (PUC-SP) Edgar Chiuratto Guimarães (Instituto Bacellar) Maria Cristina Cesar de Oliveira (UFPA)

Nelson Figueiredo (UFG)

Odilon Borges Junior (UFES)

Pascual Caiella (Universidad de La Plata - Argentina)

Emerson Gabardo (UFPR)

Paulo Eduardo Garrido Modesto (UFBA)

Paulo Henrique Blasi (UFSC)

Enrique Silva Cimma (Universidad de Chile - Chile) Eros Roberto Grau (USP)

Irmgard Elena Lepenies (Universidad Nacional del Litoral - Argentina) de La Coruña - Espanha)

Pedro Paulo de Almeida Dutra (UFMG)

Regina Maria Macedo Nery Ferrari (UFPR)

Rogério Gesta Leal (UNISC)

Rolando Pantoja Bauzá (Universidad Nacional de Chile - Chile)

Sergio Ferraz (PUC-Rio)

Valmir Pontes Filho (UFCE)

José Eduardo Martins Cardoso (PUC-SP)

José Luís Said (Universidad de Buenos Aires - Argentina) José Mario Serrate Paz (Universidad de Santa Cruz - Bolívia)

Yara Stroppa (PUC-SP)

\section{Homenagem Especial}

Guillermo Andrés Muñoz (in memoriam) Jorge Luís Salomoni (in memoriam) Julio Rodolfo Comadira (in memoriam) Lúcia Valle Figueiredo (in memoriam)

Manoel de Oliveira Franco Sobrinho (in memoriam) Paulo Neves de Carvalho (in memoriam) 


\title{
A juridicidade do Estado-administração na concretização de políticas públicas de saúde - Um método para a justificação da eficácia horizontal dos direitos fundamentais
}

\author{
Sandro Lucio Dezan \\ Doutorando em Ciências Jurídicas Públicas, na Universidade do Minho (Braga, Portugal); \\ Doutorando do Programa de Doutorado em Direitos e Garantias Fundamentais pela Faculdade \\ de Direito de Vitória - FDV (Vitória - ES, Brasil) e Doutorando em Direito e Políticas Públicas \\ no Centro Universitário de Brasília - UniCEUB (Brasília - DF, Brasil). Mestre em Direitos e \\ Garantias Fundamentais pela Faculdade de Direito de Vitória - FDV. Autor de inúmeras obras \\ jurídicas na área de Direito Administrativo Disciplinar e Direito Constitucional. Professor \\ visitante (investigador não permanente) do Mestrado em Ciências Policiais do Instituto \\ Superior de Ciências Policiais e Segurança Pública - ISCPSP (Lisboa, Portugal). E-mail: \\ $<$ sandro.dezan@gmail.com>.
}

\section{Samuel Meira Brasil Jr.}

Professor do Programa de Pós-Graduação, Doutorado e Mestrado em Direitos e Garantias Fundamentais, da Faculdade de Direito de Vitória - FDV (Vitória - ES, Brasil). Doutor e Mestre em Direito Processual pela Universidade de São Paulo - USP. Mestre em Inteligência Artificial pela Universidade Federal do Estado do Espírito Santo - UFES. Desembargador do Tribunal de Justiça do Estado do Espírito Santo. Autor de inúmeras obras jurídicas na área de Direito Processual e Constitucional. E-mail: <samuel.brasil.j@gmail.com>.

\begin{abstract}
Resumo: 0 texto busca a demonstração da possibilidade de utilização direta, independentemente de positivação normativa infraconstitucional, do valor fundamental-constitucional de proteção, corolário do direito à vida, pela Administração Pública, para a concreção do direito à saúde, em casos de medidas de urgência. Com esse objetivo, levar-se-á a efeito o desenvolvimento de argumentação jurídica, inclusive com aportes de lógica formal, para firmar os contornos, alcances e limites da legalidade estatal-executiva, a harmonizar-se com o novo plexo de normatividade do princípio da juridicidade administrativa. A pesquisa se empenha em enfoque original sobre a ampliação de autonomia da hermenêutica administrativa que, entretanto, por via paradoxal, leva à obrigatoriedade da realização do ato administrativo ótimo, para o desempenho eficiente da gestão de políticas públicas, desonerando a exaustiva intervenção do Poder Judiciário e do Ministério Público, que passariam a atuar somente post actum, nos casos de necessidade de sindicabilidade. Os métodos e as técnicas de pesquisa, a partir de uma pré-compreensão fenomenológica, firmaram-se, em dedução, na revisão bibliográfica de textos doutrinários nacionais e estrangeiros, sobre a teoria de suporte, e na análise temática da legislação pátria.
\end{abstract}

Palavras-chave: Direito à saúde. Proteção à vida. Dever de custeio pelo Estado. Princípio da juridicidade administrativa. Direito administrativo constitucionalizado.

Sumário: 1 A identificação de vinculação da Administração Pública a ações de políticas sociais de saúde - 2 A legalidade e a juridicidade nas ações de políticas públicas de saúde - $\mathbf{3}$ Os atos administrativos discricionários de proteção à saúde, a juridicidade e a aplicação imediata de direitos fundamentais 4 Considerações finais - Referências 
O princípio da proteção à saúde encontra imediato amparo nas técnicas de hermenêutica disponíveis à Administração Pública, na medida em que, independentemente de positivações diretas e expressas à atuação vinculada da função executiva estatal, seus contornos normativos são auferidos do plexo de normatividade do novel princípio da juridicidade administrativa. Isso instrumentaliza o administrador público para a contribuição efetiva na macrogestão de políticas sociais de saúde e, por outro lado, reflete crescente responsabilidade do Estado para a realização dos fins coletivos dos mais variados matizes, impondo-se, para tal mister, o emprego de novas e modernas teorias de suporte às decisões jurídicas do Estado-administração.

Sob o enfoque teórico de experimentação de um tênue distanciamento da legalidade estrita classicamente imposta à Administração e, por outro lado, de aproximação do princípio da juridicidade - o que, diante de uma visão sistêmica, não ofende a legalidade como um todo -, a pesquisa se detém à análise do espectro da normatividade pontual atinente ao direito administrativo, empregado na identificação de valores sistêmicos constitucionais e, destarte, na materialização de novas fontes diretas de condutas e de procedimentos decisionais de um Estado Social e Democrático de Direito.

A juridicidade compreende tema novo e polêmico nos meandros da teoria hermenêutica do direito administrativo brasileiro, que, por sua vez, também perfaz ramo novo das ciências jurídicas e em pleno desenvolvimento de seus institutos, que ora são obtidos por transposição de outros ramos do direito, como o fez com a utilização e a modulação de categorias normativas provenientes do direito civil, a exemplo dos atos e contratos jurídicos que deram azo aos atos e contratos administrativos; e ora identificados ou criados como próprios e peculiares, a exemplo da desapropriação por interesse público ou das normas afetas à legalidade estrita administrativa. Seja como for, à vista da contemporânea dinamicidade da hermenêutica constitucional e de sua peculiar força normativa irradiada ao direito posto infraconstitucional, tem-se identificado a necessidade de incessante aprimoramento que pervaga pela evolução da interpretação e da aplicação do direito como um todo uno e indivisível, com vista a ombrear as constantes e céleres mudanças de comportamento sociocultural.

Por essa óptica direcionada ao avanço e de refinamento teórico-dogmático dos conceitos jurídicos, a exemplo do atual entendimento de efetividade incondicional dos direitos e das garantias constitucionais fundamentais, que, por essa via, têm aplicação imediata, não sufragando dependentes de normas outras para que thes sejam conferidas legitimidade e efetividade, há de se reconhecer ao Estado, e, nesse contexto, também à sua função executiva, o dever-poder de ofertar a "melhor atuação", para a persecução do interesse coletivo, vertido em fins e interesses públicos, pelas mãos da nova hermenêutica constitucional. Há de se constatar, com efeito, não apenas o dever de eficiência, mas o dever de efetividade a regrar 
as condutas da Administração Pública, para um exercício funcional para além do legal, abarcando também o ético e o moral, como referencial histórico-cultural de um transitório, todavia racional, conceito de justiça. Isso se propicia pela busca da efetividade direita dos valores constitucionais, independentemente de judicialização. Assim, à Administração Pública, como parcela da representação executiva do Poder Público, também se apresenta esse múnus, para cuja tutela deve valer-se de métodos atuais e eficazes de hermenêutica jurídica.

Sob o amparo desses argumentos, buscaremos analisar a juridicidade como instrumento exegético manejado pela gestão executiva estatal, para a sua solução da inadequada praxe de judicialização das atribuições administrativas de concreção de políticas públicas, cujo aporte se encontra nos contornos dos direitos e garantias fundamentais.

O método decisional que ora nos propomos à pesquisa compreende os contornos materiais da vinculação do Estado ao texto normativo, princípio da legalidade, e o produto de sua evolução epistemológico-dogmática, qual seja, o princípio da juridicidade, na produção das decisões administrativas de concretização de políticas públicas de saúde.

\section{A identificação de vinculação da Administração Pública a ações de políticas sociais de saúde}

A Constituição Federal de 1988 apresenta em seu texto normativo uma série de referências à proteção à saúde, a partir de sua inclusão no rol de direitos sociais, perpassando pela competência comum da União, dos estados e Distrito Federal e municípios, incluindo a competência legislatória comum desses entes políticos, para a proteção à saúde, assim como, entre outros preceitos, os atinentes à vinculação de receitas de tributos, mormente de impostos, a investimentos em saúde da população, com ações e serviços públicos de saúde, sem embargo de todas as disposições constitucionais de seguridade social.

Dentro deste último tema, qual seja, a seguridade social, a proteção à saúde recebe destaque especial do sistema constitucional, senão vejamos:

Art. 196. A saúde é direito de todos e dever do Estado, garantido mediante políticas sociais e econômicas que visem à redução do risco de doença e de outros agravos e ao acesso universal e igualitário às ações e serviços para sua promoção, proteção e recuperação.

Art. 197. São de relevância pública as ações e serviços de saúde, cabendo ao Poder Público dispor, nos termos da lei, sobre sua regulamentação, fiscalização e controle, devendo sua execução ser feita diretamente ou através de terceiros e, também, por pessoa física ou jurídica de direito privado. 
A par dos preceitos acima expostos, não se pode prescindir da aplicação imediata das normas definidoras de direitos fundamentais, consoante o disposto no $\S 1^{\circ}$, do art. $5^{\circ}$, da $\mathrm{CF} / 1988$, ao tratar dos direitos e deveres individuais e coletivos, como modalidade dos direitos e garantias fundamentais, in verbis:

§1ํㅡ As normas definidoras dos direitos e garantias fundamentais têm aplicação imediata.

Sobre o dever de proteção à vida e à saúde, a Segunda Turma do Supremo Tribunal Federal, ao decidir o Agravo Regimental no 727.864, pautou-se pela obrigatoriedade de o Estado fornecer os meios para a garantia material de proteção aos referidos direitos fundamentais, nos seguintes termos, cujo ementário transcrevemos:

EMENTA: RECURSO EXTRAORDINÁRIO COM AGRAVO (LEI №12.322/2010) - CUSTEIO, PELO ESTADO, DE SERVIÇOS HOSPITALARES PRESTADOS POR INSTITUIÇÕES PRIVADAS EM BENEFÍCIO DE PACIENTES DO SUS ATENDIDOS PELO SAMU NOS CASOS DE URGÊNCIA E DE INEXISTÊNCIA DE LEITOS NA REDE PÚBLICA - DEVER ESTATAL DE ASSISTÊNCIA À SAÚDE E DE PROTEÇÃO À VIDA RESULTANTE DE NORMA CONSTITUCIONAL OBRIGAÇÃO JURÍDICO-CONSTITUCIONAL QUE SE IMPÕE AOS ESTADOS - Configuração, no caso, de típica hipótese de omissão inconstitucional imputável ao estado - desrespeito à constituição provocado por inércia estatal (RTJ 183/818-819) - comportamento que transgride a autoridade da Lei Fundamental da República (RTJ 185/794-796) - a questão da reserva do possível: reconhecimento de sua inaplicabilidade, sempre que a invocação dessa cláusula puder comprometer o núcleo básico que qualifica o mínimo existencial (RTJ 200/191-197) - o papel do Poder Judiciário na implementação de políticas públicas instituídas pela Constituição e não efetivadas pelo poder público - a fórmula da reserva do possível na perspectiva da teoria dos custos dos direitos: impossibilidade de sua invocação para legitimar o injusto inadimplemento de deveres estatais de prestação constitucionalmente impostos ao poder público - a teoria da "restrição das restrições" (ou da "limitação das limitações") - caráter cogente e vinculante das normas constitucionais, inclusive daquelas de conteúdo programático, que veiculam diretrizes de políticas públicas, especialmente na área da saúde (CF, arts. 6oㅡ, 196 E 197) - a questão das "escolhas trágicas" - a colmatação de omissões inconstitucionais como necessidade institucional fundada em comportamento afirmativo dos juízes e tribunais e de que resulta uma positiva criação jurisprudencial do direito - controle jurisdicional de legitimidade da omissão do poder público: atividade de fiscalização judicial que se justifica pela necessidade de observância de certos parâmetros constitucionais (proibição de retrocesso social, proteção ao mínimo existencial, vedação da proteção insuficiente e proibição de excesso) - doutrina - precedentes do Supremo Tribunal Federal em tema de implementação de políticas públicas delineadas na Constituição da República (RTJ 174/687 - RTJ 175/1212-1213 - RTJ 199/12191220) - existência, no caso em exame, de relevante interesse social. 
2. Ação civil pública: instrumento processual adequado à proteção jurisdicional de direitos revestidos de metaindividualidade - legitimação ativa do Ministério Público (CF, art. 129, III) - a função institucional do ministério público como "defensor do povo" (CF, art. 129, II) - doutrina - precedentes. 3. Responsabilidade solidária das pessoas políticas que integram o Estado Federal brasileiro, no contexto do Sistema Único de Saúde (SUS) - competência comum dos Entes Federados (União, Estados-membros, Distrito Federal e Municípios) em tema de proteção e assistência à saúde pública e/ou individual (CF, art. 23, II). Determinação constitucional que, ao instituir o dever estatal de desenvolver ações e de prestar serviços de saúde, torna as pessoas políticas responsáveis solidárias pela concretização de tais obrigações jurídicas, o que lhes confere legitimação passiva ad causam nas demandas motivadas por recusa de atendimento no âmbito do SUS - consequente possibilidade de ajuizamento da ação contra um, alguns ou todos os entes estatais - precedentes - Recurso de Agravo improvido. Decisão. A Turma, por votação unânime, negou provimento ao recurso de agravo, nos termos do voto do Relator. 2 $2^{\mathrm{a}}$ Turma, 04.11.2014.

$\mathrm{Na}$ referida decisão da Corte constitucional brasileira, da simples leitura de sua ementa e pela forma com que foi redigida, é possivel constatar os argumentos jurídicos que a sustentaram, deixando claro, assim, a ratio decidendi ou o holding basilar desse precedente não vinculante.

Em que pese não se tratar de precedente vinculante, a ratio decidendi traz à baila o conteúdo declaratório de direitos e de deveres, ao particular e ao Estado, e isso perfaz argumento de suma importância para o que defenderemos daqui para frente. Nesse sentido de vinculação que ora esposamos, imprescindível é a lição de Samuel Meira Brasil Jr., ao alinhavar que "o que vincula não é a parte dispositiva da decisão - para isso já existe a coisa julgada -, mas os fundamentos jurídicos que autorizam a conclusão" e, diante da natureza declaratória do acórdão, mister assentir que o direito e o dever já se encontravam constituídos desde a sua origem mais remota, com a demonstração pelo particular da real necessidade de assistência à saúde, antes da pretensão exercida em juízo. A natureza declaratória da decisão do STF demonstra do dever de proatividade administrativa para a tutela da vida e da saúde.

Nesses termos e do cotejo da premissa de se afigurar o direito de proteção à saúde direito fundamental social devido pelo Estado e, assim, de exercício imediato, independente de regulamentação infraconstitucional, há de se admitir imposições de concreção de valores constitucionais, a par do Estado-legislador e do Estado-juiz, ao Estado-administração, na medida em que é este, no exercício de suas funções executivas, a primeira instituição pública a deparar-se com as necessidades sociais. Deve, portanto, ser dotado de instrumentos deveras mais céleres para atendimentos de situações de urgência, a exemplo do que comumente ocorre na maioria dos casos individuais ou coletivos de proteção à saúde. 
Com efeito, há de se constatar um valor fundamental constitucional de proteção à saúde, derivado do direito à vida e submetido aos cuidados primeiramente do Estado - assim vislumbra-se uma faceta do interesse público administrativo, pela óptica do dever de concretização de direitos e garantias constitucionais fundamentais. A Administração Pública, responsável pela função executiva do Estado - e aqui deferimos, nesse papel, peculiar importância aos instrumentos jurídicos para a gestão da coisa pública, quais sejam os procedimentos e os atos administrativos e políticos de todas as sedes do Governo -, tem por fim a realização do bem comum da coletividade administrada e, diante desse contexto, encontra-se, a par de inúmeras outras atividades de relevância social, investida de importante múnus de concretização de direitos fundamentais, dentre os quais o de prover a proteção à saúde, consoante às prescrições da Constituição Federal.

Diante de todo o exposto, neste momento da abordagem, três pontos são conclusivos:

(i) A proteção à saúde compreende direito constitucional fundamental, de aplicação imediata.

(ii) Independentemente de interposição de normas outras para concreção de políticas sociais de enfrentamento, o Estado deve ater-se a essa questão, do ponto de vista da proteção incondicionada, orientando suas decisões sob o manto dos valores postos pela Constituição Federal.

(iii) A par da atuação política do governo e dos poderes Legislativo e Judiciário, a Administração Pública deve encarregar-se da concretização desse valor social constitucional, em suas funções executivas, interpretando e aplicando o direito ao caso concreto, no exercício de suas competências constitucionais e legais, para o alcance do interesse público sob sua incumbência.

Com isso, háde se deferir, partindo-se de um conceito de "função antropológica das leis", como abordado por Alain Supiot, o reconhecimento de uma função antropológica da interpretação e da aplicação administrativa das normas constitucionais, para que a Administração estatal também participe dessa concreta tutela e garantia do direito de proteção à saúde e à vida, não se deixando a cargo somente das esferas políticas de decisão tema de tão grande importância social. Os instrumentos jurídicos para esse mister pervagam pela observância dos textos normativos constitucionais e do princípio da legalidade pela óptica da plena aplicabilidade do princípio da juridicidade. 


\section{A legalidade e a juridicidade nas ações de políticas públicas de saúde}

\subsection{A lei como instrumento da Administração Pública}

A lei representa o texto normativo que dispõe sobre os direitos, os deveres e as proibições atinentes aos indivíduos submetidos à proteção territorial do Estado, todavia, envolvendo sob sua imperatividade, inclusive, esse próprio Estado em sua estrutura jurídica e orgânica. Regula, sob uma concepção de Estado Democrático de Direito, as normas de conduta entre os representados e o Estado soberano.

Inconcebível a classificação de qualquer Estado como “Democrático de Direito" sem a sua submissão à lei, esta vertida em texto normativo orientador dos limites da atuação estatal e definidor de direitos fundamentais dos indivíduos. Os poderes de governo não mais são absolutos, outrora plasmados na figura do rei, do imperador, do ditador, despótico e centralizador de funções e de assuntos das mais diversas ordens de interesses, hoje tendo na expressão dimensional do interesse público e da finalidade pública a representação dos verdadeiros deveres-poderes instrumentais ao direcionamento dos rumos da nação. Assim se constatou paulatinamente com as transformações ocorridas nas evoluções dos Estados Absoluto, Liberal e Social.

No Estado Democrático de Direito tem-se a lei como instrumento de persecução do interesse público e, não obstante, como veículo limitador dos deveres-poderes administrativos frente às liberdades individuais.

É primordialmente com fundamento nesse instituto que se constituem e se expressam os regimes jurídicos, dentre os quais o esparso jurídico-administrativo de direitos sociais, definindo os contornos do permitido, do proibido e do obrigatório para a Administração Pública nessa seara dos direitos fundamentais.

As políticas sociais sobre a proteção à saúde decorrem das mais variadas normas constitucionais, tendo como ápice os atinentes à "saúde" como direitos componentes de um plexo de valores da seguridade social, em que são traçadas as diretrizes legal-vinculativas do agir da Administração Pública, ampliadas ou especificadas pela construção do direito positivo, erigindo verdadeiro regime jurídico reitor dessa área de tutela administrativa.

Tais normas são de imprescindível relevância para a delimitação dos vieses de uma concreção e tutela de direitos, abalizadas com os direitos e garantias constitucionais fundamentais dos indivíduos e com a ordem constitucional vigente, primando pela segurança jurídica de ações realizadas.

No entanto, à vista da lei isolada, o manto da legalidade compreende-se de maior extensão, posto envolver, de modo ordenado e coerente, o sistema de normas em todos os seus aspectos intrínsecos e extrínsecos, por meio de regras e princípios jurídicos. Assim, os valores normativos, representados pelos princípios de direito, também possuem importância para o sistema. 
À vista desses argumentos, há de se considerar que a normatividade abstrata para a concreção de políticas públicas destinadas à concretização de direitos fundamentais, sociais ou individuais, não flui somente da lei, mas, também, dos princípios jurídicos de direito, complementando o plexo de valores maiores responsáveis pela condução de políticas públicas pelo Estado. Submete-se a Administração, no exercício da tutela da proteção à saúde, às leis e aos princípios componentes do ordenamento jurídico.

\subsection{Os princípios de direito como instrumentos normativos da Administração Pública na concreção de políticas sociais}

Em que pese toda a importância deferida à lei positivada, mormente pelo fato de expressar de forma mais tangivel os fins jurídicos pretendidos pelo ordenamento, a normatividade reitora do atuar estatal pode também ser aferida de preceitos mais abstratos inferidos - quando não diretamente por ele representado - do próprio texto constitucional. Dessa feita, a norma, veiculada pelas regras e princípios constantes ou hauridos dos textos normativos, compreendem as balizas do Estado Democrático de Direito. Frise-se que a lei e o ordenamento, o direito positivo, são essenciais à identificação de princípios de direito, ora referidos de forma expressa no próprio texto constitucional ou legal, ora de forma implícita no sistema normativo em seu conjunto lógico-harmonizado.

Do latim principium, o termo exprime a noção de início, começo, ou de primeiro enfrentamento sobre qualquer assunto, obstáculo, tarefa ou projeto. Os princípios jurídicos podem ser compreendidos como normas basilares, fundamentais, obtidas do direito posto, constitucional e infraconstitucional, ou mesmo de valores implícitos do ordenamento jurídico como um todo e representativos da sua essência normativa, deôntica.

A importância do estudo desses valores axiológicos funda-se na sua característica de servir como fonte normativa, na medida em que exaurem efeitos nos mesmos moldes de lei geral e abstrata, regulando, ainda que implícitos no ordenamento, a aplicação do direito ao caso concreto, vertendo-se em normas aplicáveis aos fins concretos do Estado. Também se presta ao papel de fonte interpretativa, amparando a compreensão da lei positivada, para que essa se dê dentro do seu âmbito de normatividade razoável, jurídica e socialmente aceitável, cingida aos contornos do campo conceitual dos princípios informativos que regem o ramo do direito a que está afeta.

Como fonte integrativa, aplicam-se, como estatuído no art. 4o da Lei de Introdução às Normas do Direito Brasileiro (antiga Lei de Introdução ao Código Civil), Decreto-Lei no 4.657/42, nos casos de omissões legislativas não eloquentes, em que o legislador se omite de forma não intencional no seu dever de criação de atos 
normativos gerais e abstratos, permitindo-se, com efeito, chegar-se à concretude normativa utilizando-se da harmonia do sistema jurídico como um todo.

Essa normatividade abstrata e aberta dá suporte às ações dos órgãos e entes estatais, ditando, com efeito, os rumos hermenêuticos e exegéticos, interpretativos e de aplicação, para a produção da norma de máxima concretude (o ato administrativo) pela Administração Pública, o que vale também para a concretização de políticas públicas sociais.

Constata-se que o direito da Administração Pública se utiliza do direito positivo e, não obstante, da operacionalização das normas-princípios, para o "bem cumprir" de suas ações de interesse público. Cabe ao agente estatal, operador jurídico desses casos, no exercício de funções afetas aos procedimentos de decisões, interpretar e aplicar o direito se valendo das normas constitucionais, legais (se houver) e das normas principiológicas, utilizando-se das funções hermenêuticas dessa última espécie de norma, com o fim maior de garantir o interesse público e, não obstante, a segurança jurídica de uma atuação que propicie a justa medida da realização dos valores encontrados a partir do art. 60 de nossa Constituição Federal, e demais preceitos constitucionais relacionados ao tema, mormente os encontrados nos arts. 196 e 197 do Texto Constitucional.

Os princípios e valores constitucionais são imprescindiveis a qualquer ramo do direito, e para o direito administrativo não é diferente, pois se vale, inicialmente, como primeira fonte de seus institutos, de normatividades exaradas do texto constitucional. Romeu Felipe Bacellar Filho, ao ensinar que a doutrina tradicional tem refutado a possibilidade de abertura das normas constitucionais, na medida em que texto dessa natureza e de conceito indeterminado ou demasiadamente aberto não ostentaria o status de norma, não exaurindo qualquer normatividade, esclarece que, todavia, "essa postura é incompatível com uma teoria constitucional comprometida com a supremacia material e formal da constituição", ao passo que "negar caráter normativo às regras e aos princípios constitucionais importa refutar a validade de quase todo o texto constitucional".

À vista do exposto, o gestor público, por meio dos princípios como instrumentos normativos, interpretativos e integrativos, deve caracterizar a justa causa para as decisões de garantias sociais, identificando, como afirma Niklas Luhmann, os "conceitos jurídicos adequados a sociedade". Socialmente adequados, justamente porque garantidores de concreções jurídicas alinhavadas ao "todo normativo" e obstativas de invalidades, consideradas, na acepção do referido autor, corruptores do sistema jurídico. Nas palavras de Eros Roberto Grau, "os princípios jurídicos, princípios de direito, não são resgatados fora do ordenamento jurídico, porém descobertos no seu interior", no exercício exegético de os encontrar ou os descobrir de forma pressuposta ao texto normativo a que o intérprete se dedica à pesquisa e isso se aplica não somente às searas jurisdicionais, mas também às executivas. 
Observa Eduardo García de Enterría que "têm sido os princípios descobertos e funcionalizados pelos juristas os que têm mudado, não só a ciência do Direito Administrativo, senão a vida mesma deste como ordenamento aplicado", posto que, diante de seus papeis funcional-instrumental, compõem a identidade e a individualidade do sistema, do regime jurídico e de qualquer disciplina estudada e, assim, também para a operacionalização executiva, na medida em que fornecem mais uma ferramenta à Administração Pública para alcançar e realizar os valores afetos à saúde e à vida, pensados pelo Poder Constituinte. Caracterizam-se, consoante lição de Marcello Caetano, como "uma ideia superiormente informadora de todo o sistema jurídico ou de certa parte dele, de que decorrem, portanto, as regras e soluções consagradas na legislação".

Conclui-se não se permitir desprezar a utilização dos princípios de direito, gerais ou específicos e informativos, expressos ou implícitos, na atuação da Administração Pública, para a busca da realização do interesse público, em que este compreende em seu contexto a concreção dos valores constitucionais sociais.

\subsubsection{A legalidade e a juridicidade administrativa nas ações de políticas públicas sociais}

À vista dessa acepção do princípio da legalidade, de legitimador - conquanto subordinadore limitador do mover-se da Administração Pública -, há a necessidade de conciliá-lo com o recentemente incluído em nosso ordenamento jurídico, pelo art. 2o, parágrafo único, inc. I, da Lei oํ 9.784/99, princípio da juridicidade, na medida em que ambos visam à delimitação dos contornos jurídicos das condutas administrativas, um, sob o aspecto substantivo, material, outro, sob o aspecto formal, processual ou procedimental.

Preceitua o referido dispositivo legal acima mencionado, in verbis:

Art. 2ำ A Administração Pública obedecerá, dentre outros, aos princípios da legalidade, finalidade, motivação, razoabilidade, proporcionalidade, moralidade, ampla defesa, contraditório, segurança jurídica, interesse público e eficiência.

Parágrafo único. Nos processos administrativos serão observados, entre outros, os critérios de:

I - atuação conforme a lei e o Direito [...]. (Grifos nossos)

O inciso em destaque apresenta o princípio da juridicidade, regente das atuações da administração estatal, operando-se conjuntamente com o princípio da legalidade. Impõe o dever de a Administração Pública orientar-se pela lei e pelo direito em todo e qualquer mover-se procedimental e, aqui, atentemos para dois fatos, quais sejam, (i) que a lei não necessariamente se confunde com o direito e (ii) que a expressão 
"processo", prevista na norma, possui sentido lato, amplo, para abarcar o processo em sentido estrito e o procedimento desprovido de relação em contraditório, pois não se concebe um atuar processual administrativo conforme a lei e o direito e, a contrario sensu, um atuar procedimental administrativo desarraigado desses vieses. Rege, assim, as relações jurídicas processuais simples ou investigativas, em que há somente a parte-Administração a empreender diligências, investigações, sindicâncias ou atos de instrução procedimental, e as relações jurídicas processuais, em que se forma uma relação jurídica processual bilateral, composta comumente de partes antagônicas, a exemplo do particular-requerente e da Administração-requerida, do recorrente e da Administração-recorrida, da Administração-autora e do servidor público-réu, esta última em processo disciplinar, entre outras.

Vincula o Estado-administração não somente nas suas relações públicas em contraditório, mas também nas formalizações, desenvolvimentos e conclusões de procedimentos, quaisquer que sejam eles, (i) propriamente administrativos de efeitos interna corporis, ou (ii) extramuros, de efeitos externa corporis, a exemplo dos procedimentos de licenciamentos ambientais, que envolvam pessoas físicas, ou jurídicas de direito privado.

Obriga a Administração Pública e o administrador responsável pelas tomadas de decisões em sede de políticas ambientais à observância não só da lei, mas do direito, na condução de seus procedimentos, independentemente de serem eles, os procedimentos, voltados internamente para se experimentarem efeitos dentro dos próprios meandros da Administração ou externamente, e.g., em sede particular, ou judicial. 0 direito, em sua acepção distinta da lei estrita, encontra-se, como ciência dogmática, na ordem do dia, para a Administração Pública encarregada da concreção de políticas públicas ambientais, em que os valores postos pelo sistema normativo encorpam o plexo de recursos postos ao hermeneuta e aplicador do direito administrativo, instrumentalizando-o para não ser um autômato da mecânica subsunção do conceito do fato ao conceito da norma, mas sim para identificar o núcleo normativo que materialize, em cada decisão administrativa, os valores postos pela Constituição Federal.

Discorrendo sobre o princípio da juridicidade, J. J. Gomes Canotilho acentua a importância para os sistemas normativos de se atuar sob o manto do direito, em sua acepção não somente normativa, mas sim científica e valorativa, de normatividade indireta, assinalando que o direito, como refletivo de uma comunidade organizada, que estabelece regras e medidas e prescreve formas e procedimentos, compreende medida material e formal da vida do corpo social, sendo, por isso, indissociável da realização e da concretização da justiça e dos valores - econômicos, sociais e culturais - a ela relacionados.

Eros Roberto Grau afirma haver ainda várias concepções para o termo direito em sua vertente de ciência do direito, quais sejam "a Filosofia do Direito, a Teoria 
Geral do Direito, a História do Direito, a Sociologia do Direito, a Dogmática Jurídica ou Jurisprudência teórica" e estas - impreterivelmente e dentro de um critério de razoabilidade aplicado aos fins de qualquer tomada de decisões administrativas relacionadas a fatos e pessoas - são objetos de trabalho das autoridade administrativas na concretização dos valores estampados na constituição Federal de 1988. O administrador público é, também, e a exemplo do corrente nos demais poderes da República, operador do direito, quer seja ele representado sob a acepção de texto legal, quer sobre a acepção normativa de princípios de direito, ou, ainda, sob as noções de direito como ciências jurídicas.

Assim, para quaisquer cadernos procedimentais dedicados à satisfação do interesse público, partindo-se da premissa de que cabe à Administração Pública, a par da precípua função atinente ao Poder Judiciário, o dever de interpretar e aplicar o direito ao caso concreto posto à sua decisão, o princípio da legalidade, em harmonia com o princípio da juridicidade, delimita o agir do Estado concretizador e executor de políticas públicas e garantia de um de persecução dos fins públicos, consoante os preceitos legais em sentido lato e, assim, em harmonia com o direito, englobando seus princípios, regras e valores.

De fato, não se afasta o princípio da legalidade, mas tão somente se amplia o seu alcance, para incluir em seu bojo o plexo de valores que caminha em consonância com o texto da lei interpretada, consubstanciando campo fértil de incidência e de especial força normativa ao novel princípio da juridicidade, ou da atuação conforme a lei e o direito. Esse importante instrumento de realização do interesse público é afeto não ao locus das realizações materiais diretamente, mas, sim, ao da funcionalização procedimental-processual administrativa e impõe a atuação da Administração não somente em conformidade com os limites objetivos da lei, mas segundo o alcance subjetivo do direito, como um todo. Para o Estado, no ambiente jurídico-administrativo de perfil procedimental-processual, a lei é o seu ponto de partida e o direito, como ciência dogmática, a sua fronteira intransponivel e que se presta sobremaneira à gestão administrativa dos riscos ambientais.

Em resumo, duas balizas se apresentam como impositivas de observância pela autoridade administrativa na realização executiva de valores ambientais: a lei, e o decorrente princípio a legalidade, e o direito, compreendido como a juridicidade auferida da ciência do direito, para autorizar a condução das questões ambientais com discricionariedade, autonomia, isenção e imparcialidade. O dever de juridicidade dá, à autoridade encarregada da tomada de decisões ambientais, esse dever de atuação de acordo com seu livre convencimento técnico-jurídico (juridicidade administrativa). 


\subsubsection{A legalidade e a juridicidade administrativa e a aplicação direta da proteção à saúde pela Administração Pública}

Considerando o exposto, em que discorremos sobre a normatividade exarada pelos princípios de direito para orientar e vincular as ações da Administração Pública, inclusive em sede de sua atuação em políticas públicas constitucionais, há de se ponderar o tema à vista da atividade de gestão eficiente e efetiva requerida do Estado-administração, a qual passa, sem embargo do princípio da legalidade, por aplicação do princípio da juridicidade como conceito normativo que contém em seu espectro cognoscivel a necessidade de reconhecimento da eficácia horizontal dos direitos fundamentais constitucionais.

Para tanto, percorreremos o silogismo dedutivo que terá como ponto de partida a juridicidade administrativa nas ações discricionárias do Estado, as quais devem ser regidas pela razoabilidade. Com isso, impõe-se, como ensina Celso Antônio Bandeira de Mello, a necessidade de confecção do ato administrativo discricionário ótimo e, do ponto de vista de concreção de valores sociais, pervaga, como ponto de chegada, no reconhecimento da eficácia horizontal de direitos fundamentais, com a aplicação imediata e incondicionada, como expressão da juridicidade administrativa para a concreção de políticas públicas.

Abordaremos, assim, nos subitens subsequentes os atos administrativos discricionários de direito de proteção à saúde sob o enfoque da razoabilidade e da juridicidade, para, ao final, relacionarmos a juridicidade como instrumento hermenêutico de materialização do ato administrativo ótimo, sob o prisma do interesse público social-protetivo, reflexivo dos valores "direito à saúde" e "direito à vida", plasmados na Constituição Federal.

\section{Os atos administrativos discricionários de proteção à saúde, a juridicidade e a aplicação imediata de direitos fundamentais}

O princípio da legalidade prescreve que a Administração Pública deve agir conforme o estatuído em lei. Todavia, as modernas técnicas de hermenêutica administrativas sugerem que há de se compor a legalidade com a juridicidade e isso se transmuda para uma imposição quando o administrador público se depara com atribuições para decisões que se pautam em atos discricionários, ou seja, diante das margens discricionárias permitidas por lei ao gestor, no momento de exercício da decisão administrativa.

Marcello Caetano discorre sobre o ato discricionário e esclarece que essa categoria compreende o ato administrativo que se baseia em juízo de conveniência e de oportunidade a ser sopesado pelo órgão encarregado de sua elaboração, posto 
que, sobre os vértices de baliza estipulados pele lei, esta não firma taxativamente a posição a ser tomada pela Administração, permitindo-se, em cada caso, o exame dos "aspectos concretos em que tem de prosseguir o interesse público e a escolha, segundo o seu critério, da conduta mais conveniente a qual, dentro dos limites traçados, será considerada legal".

A doutrina clássica considera que o mérito do ato administrativo discricionário, concebido - a par dos elementos vinculados do ato: "sujeito competente", "forma prevista em lei" e "finalidade legal" - pelos seus elementos de validade "motivo" e "objeto", não se submete à lei, mas tão somente ao juízo de conveniência e de oportunidade do gestor público, encarregado pela edição do ato administrativo. Desse modo, sustenta-se não caber sopesamento do mérito do ato administrativo discricionário pelo Poder Judiciário, uma vez que, se assim procedesse, estar-se-ia a substituir o juízo de valor legítimo do Poder Executivo, por outro juízo de valor, no caso ilegítimo, do Poder Judiciário, que não detém a função legal de gestão estatal e ou de concretização de políticas públicas administrativas. Esses argumentos sustentam uma face da tese contrária ao ativismo judicial.

A doutrina mais recente argumenta que o mérito do ato administrativo discricionário deve ser balizado pelos juízos de razoabilidade e de proporcionalidade, os quais, não obstante, compreenderiam não uma invasão jurisdicional no juízo de mérito do administrador, mas tão somente uma análise de estrita legalidade desse exercício de sopesamento meritório administrativo. Como exemplo, podemo-nos referir à hipotética sanção administrativa que, face à lei em abstrato, delineie punição à empresa poluidora, em que o conteúdo da pena varie, de acordo com o dano causado ao meio ambiente, entre a advertência, a repreensão, a multa (com estipulação de valores mínimo e máximo), a suspensão das atividades (com a estipulação de período mínimo e máximo) e a interrupção definitiva das suas atividades. No exemplo citado, a lei apresenta os parâmetros discricionários da sanção administrativa, que pervaga, gradativamente, da advertência à interrupção definitiva das atividades da empresa, vinculando-os, ainda, à gravidade do dano em concreto. 0 legislador deixou explícito, pela disposição topográfica das sanções, uma ordem crescente de rigidez administrativo-penal, retributiva e corretiva, que perfaz a mens legis de proporcionalidade e de razoabilidade a ser empregada pelo intérprete e aplicador da norma. Esse fator impõe ao agente público encarregado da decisão de concretização da sanção que, embora exercendo o juízo de conveniência e oportunidade para a prática do ato, quede-se adstrito, por razões de princípios maiores tais quais a certeza e a justiça do direito, aos limites de proporcionalidade e de razoabilidade exigidos caso a caso. Desse modo, exempli gratia, para pequenos danos ao meio ambiente, desprovidos de riscos, não poderia sancionar a empresa, de plano, com a interrupção de suas atividades. Acaso o administrador afaste-se dessa proporcionalidade ou 
razoabilidade o Poder Judiciário encontrar-se-á legitimado, desde que provocado pelo interessado jurídico, ao procedimento dessa análise de legalidade e, sendo o caso, à anulação do ato administrativo sancionador.

Com isso, aferem-se os atos discricionários como aqueles em que a Administração Pública age movida por conveniência ou oportunidade, dentro de parâmetros de razoabilidade e de proporcionalidade, permitidas por lei. Esta deixa espaço de escolha, sob o enfoque da conveniência e da oportunidade, ou do denominado plexo de ação decisória do mérito do ato administrativo, para o gestor administrativo, diante dos motivos determinantes apresentados, conduzir o aparato estatal, de forma ativa ou omissiva, ao resultado desejado, dentro das margens previstas em lei.

Difere, assim, dos atos vinculados, em que a lei não oferece margem de escolha e ponderação ao administrador, posto ter previsto, por obra legislativa preconcebida, todo o iter de conduta da Administração, desde a situação hipoteticamente apresentada, ao percurso procedimental a ser percorrido e ao resultado a alcançar. Sob o primado da vinculação legal "não é livre a Administração Pública de resolver sobre a conveniência do ato, nem sobre seu conteúdo. Só lhe cabe constatar a ocorrência dos motivos e, com base neles, praticar o ato", ao passo que sobre a égide da discricionariedade, o mérito do ato administrativo, o conteúdo e o objeto ficam a cargo do juízo de conveniência e de oportunidade do gestor público, todavia sob os limites legais da razoabilidade e da proporcionalidade, o que aqui classificamos como (i) razoabilidade comum. Esta, para os fins de nossa abordagem temática, compreende os aspectos de razoabilidade e de proporcionalidade, descritos ou aferidos da lei específica e vinculativos do mérito do ato administrativo discricionário.

Sem embargo dessa acepção, que ainda se perfaz majoritária na doutrina e na jurisprudência, a teoria tem evoluído para limitar essa margem de liberdade da Administração para a prática dos atos discricionários, jungindo o juízo de conveniência e de oportunidade à correta - ou razoável e proporcional - identificação do interesse público a ser almejado à luz do caso concreto, posto que somente há de haver um único ato ótimo a realizar por completo o interesse público concretamente posto em jogo. Essa característica concebível a orientar o intérprete e aplicador do direito administrativo na busca da edição do único ato adequado ao caso concreto denominamos (ii) razoabilidade qualificada.

A base teórica fundamenta-se na tese crítica ao positivismo jurídico de Herbert Lionel Adolphus Hart, formulada por Ronald Dworkin, em sua obra Levando os direitos a sério, em que, em resposta à obra $O$ conceito de direito de Hart, assenta, por meio da "metáfora do juiz filósofo Hércules", não se legitimar possibilidades de mais de uma decisão, para casos supostamente solucionáveis por critérios discricionários do julgador. Para Dworkin, diante da discricionariedade, somente há uma solução que melhor se amolda ao caso concreto judicializado, que se dá com a utilização de princípios jurídicos, ou mesmo morais, adequados. 
Esse também é o entendimento de Celso Antônio Bandeira de Mello, ao desenvolver importante estudo da atuação discricionária da Administração Pública, afirmando que, nesses casos, contrariamente ao que se tem defendido na doutrina e na jurisprudência majoritária, o Estado-administração encontra-se obrigado a praticar, por imperativos de razoabilidade e de proporcionalidade, o ato administrativo ótimo, dentro dos limites permitidos por lei. Assim, se há a faculdade de agir ou de se omitir e se decide de um ou de outro modo, essa medida deve refletir a melhor conduta, considerada à vista das possibilidades lógico-normativas à disposição do Estado.

Prescreve Bandeira de Mello que, a exemplo do ato vinculado:

discrição [...] é a mais completa prova de que a lei sempre impõe o comportamento ótimo [...] [posto que] quando a lei regula discricionariamente uma dada situação, ela o faz deste modo exatamente porque não aceita do administrador outra conduta que não seja aquela capaz de satisfazer excelentemente a finalidade legal.

Transpondo as ponderações acima expostas para o campo das questões de proteção à saúde afetas à gestão da Administração Pública, há de se concluir que, sob a normatividade dos valores expressos na Constituição Federal de 1988, e face à probabilidade de graves danos aos administrados ou de suas irreversibilidades, não há discricionariedade administrativa. A Administração tem o dever de buscar o ato administrativo ótimo para a proteção dos administrados e a concreção dos direitos à saúde e à vida, e, como expressão dessa qualificação do ato, constata-se a eficácia horizontal dos direitos fundamentais a vincular a atuação também do Estado gestor de políticas públicas sociais.

Diante da imposição de aplicação imediata de direitos fundamentais, em que se consistiria esse ato ótimo, para a efetiva e eficaz gestão de políticas sociais? Imperioso se aceitar a eficácia horizontal desses direitos constitucionais, por meio do princípio da juridicidade, como expressão desse ato administrativo sui generis.

Com efeito, apresenta-se a utilização da eficácia horizontal dos direitos fundamentais como instituto jurídico imprescindivel ao alcance do (i) resultado ótimo, do ponto de vista da plena realização dos valores dos direitos à vida e à proteção da saúde, contidos na Constituição Federal de 1988, e que se devem orientar pelo imperativo de uma (ii) razoabilidade qualificada, a compor ou a modular os requisitos de validade dos (iii) atos administrativos, vinculados ou discricionários, como expressão de gestão eficiente, firmada em decisões ou em edições de atos ótimos.

Em síntese e partindo-se do que estudiosos têm apontado como uma problemática jurídica que se mantém de longa data, qual seja a de que "embora tenhamos avançado em termos interpretativos, não resolvemos o problema da aplicação, isto é, da decisão", busca-se com todo o exposto uma teoria para a fundamentação das decisões administrativas de políticas sociais de urgência. 
O fluxograma ilustra a tese ora esplanada:

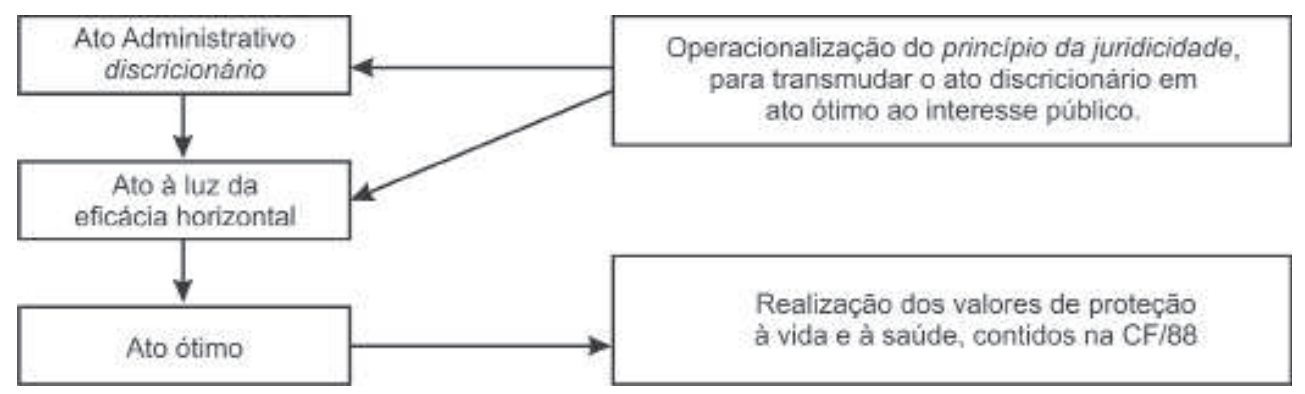

Ainda se pode representar esse influxo normativo de modo mais detalhado por meio de formulação matemático-simbólica, com o emprego das teorias da lógica formal, submetendo-se os argumentos já apresentados ao exame do discurso em uma estrutura proposicional $-^{1}$ afastando-se, todavia, do modelo dogmático caracterizado pelo ontologismo verbal, ${ }^{2}$ posto este se distinguir pela carga de valores axiológicos contida na formulação -, em que se apõem as regras jurídicas atinentes à temática ao jugo da razão dos valores jurídicos, que as condicionam, limitam e fornecem-lhe legitimidade e efetividade. Sob esse novo olhar, temos a razão assim representada entre regras e valores, para a obtenção do ato administrativo de proteção de direitos sociais:

\footnotetext{
1 Sobre o tema conferir: ALVES, Alaôr Caffé. Lógica, pensamento formal e argumentação. Elementos para o discurso jurídico. 5. ed. São Paulo: Quartier Latin, 2011; BITTAR, Eduardo C. B. Linguagem jurídica. 2. ed. São Paulo: Saraiva, 2006; COELHO, Fábio Ulhôa. Roteiro de lógica jurídica. São Paulo: Max Limonad, 1996; FERRAZ JUNIOR, Tercio Sampaio. Introdução ao estudo do direito: técnica, decisão, dominação. 4. ed. São Paulo: Atlas, 2003; PERELMAN, Chaïm. Lógica jurídica: nova retórica. São Paulo: Martins Fontes, 2004; VILANOVA, Lourival. Escritos jurídicos e filosóficos. 1. ed. São Paulo: Ibest, 2003. v. 1 e 2; MARTARI, Cezar A. Introdução à lógica. São Paulo: Unesp, 2001; PRADO JÚNIOR, Caio. Introdução à lógica dialética: notas introdutórias. 4. ed. São Paulo: Brasiliense, 1979; LANGER, Susanne K. An introduction to symbolic logic. Boston: Houghton Miffelin Company, 1937; HOTTOIS, Gilbert. Pensar a lógica. Uma introdução técnica e teórica à filosofia da lógica e da linguagem. Tradução de Miguel Mascarenhas. Lisboa: Instituto Piaget, 2004.

2 Esse modelo dogmático de interpretação e aplicação da lei, com a utilização do denominado "alfabeto jurídico universal”, teve em Ihering seu principal defensor, que entendia tratar-se de formulação de fácil compreensão, como forma de expressar claramente a vontade da lei (VON IHEING, R. Espíritu del derecho romano em las diversa etapas de su desarrollo. La dogmática jurídica. Buenos Aires: Losada, 1946). Todavia, distinguimo-nos aqui do ontologismo verbal estrito, na medida em que incluímos (diferentemente de lhering, que se deteve ao texto de lei positivado, com submissão expressa à da corrente filosófica positivista) os valores principiológicos auferidos do sistema de normas como um todo, mormente os constitucionalmente qualificados, na esteia das teorias de Robert Alexy, ao contrapor constitucionalismo e legalismo e firmar-se na razão apoiada na Constituição (ALEXY, Robert. Teoría de los derechos fundamentales. Madrid: Centro de Estudios Políticos y Constitucionales, 2002). Conferir também, sob o prisma da defesa dos argumentos analógicos, a par dos dedutivos e indutivos na linguagem jurídica, WEINREB, Lloyd L. A razão jurídica. $\mathrm{O}$ uso da analogia no argumento jurídico. São Paulo: Martins Fontes, 2008. Como afirma Émile Durkheim (Sociologia e filosofia. Tradução de Fernando Dias Andrade. São Paulo: Martin Claret, 2009. p. 13), "em suma, a analogia é uma forma legítima da comparação e a comparação é o único meio prático de que dispomos para conseguir tornar as coisas inteligíveis".
} 


\section{$\mathrm{R}$ \\ V}

Em que o símbolo $\mathbf{R}$ representa as regras positivadas e o $\mathbf{V}$ reporta-se aos valores aferidos no interior do sistema normativo. 0 símbolo de razão ou de divisão, representado por um traço na posição horizontal, indica a relação existente entre o dividendo e o divisor, entre o objeto da racionalização e o racionalizador, em que o primeiro é modulado e limitado à luz das teorias que envolvem o segundo. Por outras palavras, as regras de direito positivo são interpretadas ou racionalizadas à razão dos valores jurídicos, obtendo-se, como produto ou quociente, o resultado do processo hermenêutico, que, no caso no qual ora nos detemos, refere-se ao ato administrativo de proteção de direitos sociais firmado na eficácia horizontal dos direitos fundamentais constitucionais.

Diante dessa compreensão e convertendo em formulação as inter-relações jurídicas que se dão entre o ato administrativo de caráter social, o princípio da legalidade e princípio da juridicidade, sob um prisma da razoabilidade enquanto noção de conduta social e juridicamente adequada aos fins almejados, afere-se o ato administrativo discricionário, e, com a adição do princípio da juridicidade, o ato administrativo discricionário ótimo, ou seja, o ato administrativo social de proteção à vida e à saúde.

Assim, para o ato administrativo discricionário simples, para o qual não se opera sopesamento de valores sensiveis, temos:

$$
\frac{(\mathrm{Rc}+\mathrm{Fs}+\mathrm{For}+\mathrm{Md}+\mathrm{Obd}) \times \mathrm{L}}{\mathrm{pLg}}=\mathrm{Ad}
$$

Em que:

L - Lei

Ad - Ato discricionário simples

Rc - Regra legal de competência (autoridade competente para a prática do ato)

Fs - Finalidade simples (móvel objetivamente previsto em lei)

For - Forma

Md - Motivo discricionário (sob a orientação da conveniência e da oportunidade)

Obd - Objeto discricionário (sob a orientação da conveniência e da oportunidade)

pLg - Princípio da legalidade (concordância sistêmica com o ordenamento jurídico)

Md + Obd - Mérito do ato administrativo, balizado objetivamente pelo direito positivo 
Na posição de "dividendo", ou de submetidos à racionalização ou à razão, encontram-se os elementos de validade do ato administrativo discricionário simples, ${ }^{3}$ representados pelos símbolos Rc, Fs, For, Md e Obd, estipulados por lei (representada pelo símbolo L). Com efeito, têm-se a competência, a finalidade, a forma, o motivo e o objeto do ato administrativo, todos com a necessidade de previsão em lei. Essa necessidade de previsão em lei se dá com a inserção do sinal de multiplicação.

Os pressupostos de validade do ato encontram-se à razão do princípio da legalidade, representado pelo símbolo pLg, e, com isso, sob a necessidade de guardar-se concordância sistêmica com o ordenamento jurídico. Dessa feita, não basta simplesmente a lei ter instituído os elementos de validade para a prática do ato administrativo. Faz-se imperiosa a observância de todo o ordenamento de direito, sob os seus aspectos positivados e deles decorrentes, exempli gratia, da perfeita harmonia com o devido processo legal material ou substantivo, substantive due process. Feito isso, chega-se ao quociente procedimental ou ao resultado do ato em si, compreendido como a edição do ato administrativo simples ou não qualificado, em harmonia objetiva com o ordenamento jurídico.

Contudo, em temas de políticas sociais urgentes, em que se inserem os direitos à vida e à saúde, e, como acima amplamente comentado, diante da necessidade de concreta realização desses valores contidos na Constituição Federal, há de se requerer uma harmonia subjetiva com o ordenamento jurídico, para a efetiva e eficaz gestão da temática pela Administração Pública, e isso se obtém, como assinalado alhures, com a operacionalização da eficácia horizontal de direitos fundamentais como faceta do princípio da juridicidade administrativa.

Com a inclusão do princípio da juridicidade à formulação obtém-se o ato administrativo de proteção de direitos sociais juridicizado ou qualificado, cujo conteúdo jurídico se distingue do ato administrativo simples ou não qualificado, pela inclusão e sopesamento de valores jurídicos sensíveis, quais sejam a razoabilidade comum, a razoabilidade qualificada:

$\frac{[\mathrm{Rc}+\mathrm{Fs}+\mathrm{For}+\mathrm{Rzc}(\mathrm{Md}+\mathrm{Obd})] \times L=\text { Aaj }}{\mathrm{pLg}+\text { pJur f (Vlj } \times \mathrm{Rzq})}$

\footnotetext{
3 Para estudo detalhado dos elementos de validade do ato administrativo, conferir: HAURIOU, André. A utilização em direito administrativo das regras e princípios do direito privado. Revista de Direito Administrativo, v. I, n. 2, tradução de Paulo da Mata Machado, 1945; HAURIOU, Maurice. Précis de droit administratif et de droit public. Paris: Recueil Sirey, 1933; HORBACH, Carlos Bastide. Teoria das nulidades do ato administrativo. 2. ed. São Paulo: Revista dos Tribunais, 2010; HORBACH, Carlos Bastide. Direito administrativo e privado na obra de Ruy Cirne Lima. Belo Horizonte: Fórum, 2009; e MEIRELLES. Hely Lopes. Direito administrativo brasileiro. 24. ed. São Paulo: Malheiros, 1999.
} 
Em que:

$\mathrm{L}-$ Lei

Aaj - Ato administrativo juridicizado

Rc - Regra legal de competência (autoridade competente para a prática do ato)

Fs - Finalidade simples (móvel objetivamente previsto em lei)

For - Forma

Md - Motivo discricionário (sob a orientação da conveniência e da oportunidade)

Obd - Objeto discricionário (sob a orientação da conveniência e da oportunidade)

pLg - Princípio da legalidade (concordância sistêmica com o ordenamento jurídico)

Rzc - Razoabilidade comum (proporcionalidade e razoabilidade da conduta administrativa, balizada objetivamente pelo direito positivo)

pJur - Princípio da juridicidade (dever de atuação conforme a lei e o direito)

Vlj - Valor jurídico (direitos à vida e à saúde)

Rzq - Razoabilidade qualificada (finalidade de busca do ato ótimo, pela aplicação da eficácia horizontal dos direitos fundamentais)

f - Sinal relacional com significado de "em função de"

Rzc $(M d+O b d)-$ Mérito do ato administrativo, balizado objetivamente pelo direito positivo, sob o crivo da razoabilidade.

pJur $\mathbf{f}(\mathrm{Vlj} \times \mathrm{Rzq})$ - Juridicidade do ato administrativo

$p L g$ + pJur f (Vlj x Rzq) - essa formulação, composta de valores principiológicos e que encontra-se caracterizada na posição de "divisor" ou "racionalizador", pode ser entendida como uma finalidade qualificada do ato administrativo de concreção de políticas públicas sociais de urgência $(\mathrm{Fq})$.

A distinção entre a primeira fórmula, afeta ao ato discricionário simples ou não qualificado, e a segunda fórmula, em que se afere o ato administrativo de proteção de direitos sociais, cinge-se à inclusão, no dividendo matiz, junto aos elementos de validade do ato administrativo e empenhado em modular os efeitos jurídicos do mérito administrativo fornecidos pelo "motivo" e pelo "objeto" do ato, do princípio da razoabilidade comum, representado pelo símbolo Rzc. Classificamo-lo de "comum", haja vista possuir o conteúdo ordinário, reconhecido pela doutrina clássica, ${ }^{4} \mathrm{em}$ que, concomitantemente com os elementos vinculados do ato administrativo (competência, finalidade e forma), fornecem o conjunto de elementos de validade do ato administrativo. Anote-se, porém, que para parte da jurisprudência esse primeiro elemento incluído na formulação, qual seja a razoabilidade comum, também é posto a influenciar o mérito dos atos administrativos não juridicizados, para permitir ao Poder

4 Por todos: BANDEIRA DE MELLO, Celso Antônio. Curso de direito administrativo. 10. ed. São Paulo: Malheiros, 1997. 
Judiciário o juízo, sob um aspecto de legalidade, da conveniência e da oportunidade de sua prática. ${ }^{5} \mathrm{O}$ mérito desse ato administrativo deve ser objetivamente razoável, compreendendo apresentar um motivo e um objeto com contornos fáticos que não ultrapassem o que se espera ou o que já se tenha validamente praticado para atos semelhantes, dentro de um espectro de não ineficácia e de não excesso.

No "divisor", na posição em que colocamos os valores jurídicos modulativos dos elementos de validade do ato administrativo, inserimos, a par do princípio da legalidade, o princípio da juridicidade, representado pelo símbolo pJur, que opera somando-se ao princípio a legalidade e, todavia, em função de um especial valor jurídico sensível, qual seja a eficácia horizontal dos direitos à vida e à proteção da saúde, representado por Vlj. Este último, por sua vez, tem seu conteúdo dado em razão da reação propiciada pela incidência de uma razoabilidade qualificada, representada por Rzq, que compreende a necessidade de se buscar o "ato ótimo", ${ }^{6}$ do ponto de vista da realização do interesse público em sede de políticas públicas sociais de urgência.

Vertendo a formulação matemático-simbólica em formulação de lógico-formal, sintática e semântica proposicionais, temos a seguinte proposição formal:

$$
\begin{gathered}
\mathrm{L} F\{[\mathrm{Rc} \wedge \mathrm{Fs} \wedge \text { For }] \wedge[\mathrm{Rzc} F(\mathrm{Md} \wedge \mathrm{Obd})]\} \mathbf{f}\left\{\left[\left(\left(\mathrm{L} \wedge \mathrm{Vlj}_{1} \wedge \mathrm{Pap}\right) \rightarrow \mathrm{Rjn}\right)\right.\right. \\
\left.\mathrm{pLg}] \wedge\left[\left(\mathrm{Rzq} \rightarrow \mathrm{Vlj}_{2}\right)-\mathrm{pJur}\right]\right\}
\end{gathered}
$$

Em que:

\{ \} Corresponde aos símbolos denominados "chaves", indicativos de conjunto, em que os símbolos contidos entre eles pertencem ao mesmo conjunto.

[ ] Corresponde aos símbolos denominados "colchetes", indicativos de subconjunto, contido no conjunto formado pelas chaves.

( ) Corresponde aos símbolos denominados "parênteses", indicativos de subconjunto do subconjunto formado pelos colchetes, contidos no conjunto formado pelas chaves.

- Corresponde ao símbolo relacional denominado "martelo sintático", indicando que "os símbolos subsequentes, contidos em um conjunto específico, derivam do símbolo antecedente".

$\wedge$ Corresponde ao símbolo relacional de "conjunção ou aditivo".

f Sinal relacional com significado de "em função de".

\footnotetext{
5 Como visto em nota alhures, a Sexta Turma do Superior Tribunal de Justiça já assentou que “não há confundir a análise do mérito administrativo, que é de exclusividade da Administração por exigir juízo de valor acerca da conveniência e oportunidade do ato, com o exame de eventual ofensa ao princípio da proporcionalidade, que acarreta na ilegalidade e nulidade do ato e, portanto, é passível de ser examinada pelo Poder Judiciário" (REsp no 876.514/MS).

6 Teses de Dworkin e Bandeira de Mello.
} 
= Corresponde ao símbolo relacional denominado "martelo semântico", indicando que "o símbolo subsequente é uma consequência dos conjuntos de símbolos antecedentes".

$\rightarrow$ Corresponde ao símbolo relacional "se, então", com função implicacional, em que o símbolo antecedente implica o símbolo subsequente.

L - Lei

Aaj - Ato administrativo juridicizado

$\mathrm{Rc}$ - Regra legal de competência (autoridade competente para a prática do ato)

Fs - Finalidade simples (móvel objetivamente previsto em lei)

For - Forma prescrita em lei

Md - Motivo discricionário (sob a orientação da conveniência e da oportunidade)

Obd - Objeto discricionário (sob a orientação da conveniência e da oportunidade)

pLg - Princípio da legalidade (concordância sistêmica com o ordenamento jurídico)

Rzc - Razoabilidade comum (proporcionalidade e razoabilidade da conduta administrativa, balizada objetivamente pelo direito positivo)

pJur - Princípio da juridicidade (dever de atuação conforme a lei e o direito)

$\mathrm{Vlj}_{1}$ - Princípios gerais do direito (valor jurídico)

$\mathrm{Vlj}_{2}$ - Eficácia horizontal dos direitos à vida e à proteção da saúde (valor jurídico)

Pap - Postulados jurídicos aplicativos

Rjn - Regime jurídico-normativo

Rzq - Razoabilidade qualificada (finalidade de busca do ato ótimo, por meio da eficácia horizontal dos direitos fundamentais constitucionais)

[Rc $\wedge \mathrm{Fs} \wedge \mathrm{For}]-$ Elementos vinculados de validade do ato administrativo discricionário $(\mathrm{Md} \wedge \mathrm{Obd})-$ Elementos discricionários de validade do ato discricionário: mérito do ato administrativo discricionário, sob juízo de sopesamento estrito do agente público encarregado pela prática do ato administrativo.

[Rzc $\vdash(\mathrm{Md} \wedge \mathrm{Obd})]$ - Argumento proposicional formal que se refere ao mérito do ato administrativo discricionário, sobre o crivo da razoabilidade legalizada ou comum, ditada por lei.

$L F\{[R c \wedge F s \wedge$ For $] \wedge[R z c F(M d \wedge O b d)]\}-$ Argumento proposicional formal que elenca os elementos de validade do ato administrativo discricionário e a relação entre eles, demonstrando que todos os seus elementos derivam da lei e que, especificamente, o motivo e o objeto do ato derivam da razoabilidade comum.

$\left[\left(\left(\mathrm{L} \wedge \mathrm{Vlj}_{1} \wedge \mathrm{Pap}\right) \rightarrow \mathrm{Rjn}\right) \vdash \mathrm{pLg}\right]-$ Argumento proposicional formal que demonstra que a lei em si, os valores jurídicos representados pelos princípios gerais do direito e os postulados aplicativos formam ou implicam o regime jurídico sistematizado, conjunto do qual se deriva o princípio da legalidade.

$\left[\left(\mathrm{Rzq} \rightarrow \mathrm{Vlj}_{2}\right) \vdash\right.$ pJur $]$ - Argumento proposicional formal que representa a juridicidade qualificada do ato administrativo, declinando que a busca do ato ótimo implica o 
reconhecimento e a utilização da eficácia horizontal dos direitos à vida e à proteção da saúde, dando azo ao princípio da juridicidade administrativa. A juridicidade administrativa, à vista desses fatores, transforma-se em uma juridicidade qualificada pela concreção de valores constitucionais.

$\left[\left(\left(\mathrm{L} \wedge \mathrm{Vlj}_{1} \wedge \mathrm{Pap}\right) \rightarrow \mathrm{Rjn}\right) \vdash \mathrm{pLg}\right] \wedge\left[\left(\mathrm{Rzq} \rightarrow \mathrm{Vlj}_{2}\right) \vdash\right.$ pJur $]$ - Argumento proposicional formal que demonstra a relação de adição entre o princípio da legalidade e o princípio da juridicidade qualificada, sendo que este último ainda deriva da relação implicacional existente entre a razoabilidade qualificada e os valores "direito à vida" e "direito à proteção à saúde".

\section{Considerações finais}

Interpretando a proposição lógica exposta, chegam-se aos mesmos resultados da formulação matemático-simbólica já explanada, quais sejam:

(i) Há dois macroconjuntos de elementos, em que o primeiro representa o ato administrativo e seus elementos de validade e o segundo representa os valores principiológicos hauridos do sistema jurídico como um todo.

(ii) O primeiro macroconjunto é analisado em função do segundo macroconjunto, submetendo-se as regras aos valores jurídicos.

(iii) No primeiro macroconjunto, (iii.a) os elementos de validade do ato administrativo discricionário derivam de estipulações legais e são formados por elementos vinculados e por elementos discricionários; e (iii.b) os elementos de validade discricionários, formados pelo motivo e pelo objeto do ato, dão azo ao mérito do ato administrativo discricionário; assim como (iii.c) o mérito desse ato administrativo discricionário submete-se à análise da razoabilidade comum, como um aspecto de análise da legalidade, uma vez que é a lei quem dita, de forma topográfica, a margem gradual de mobilidade da conduta administrativa.

(iv) No segundo macroconjunto, (iv.a) a legalidade deriva da noção de sistema jurídico-normativo, em que este é composto pela lei, por princípios gerais do direito e por postulados jurídicos aplicativos; (iv.b) a confecção desse ato administrativo, com o fim de produzir o ato administrativo de proteção de direitos sociais, deve ser sopesada em função do "princípio da legalidade" e do "princípio da juridicidade"; e (iv.c) a razoabilidade qualificada, correspondente à busca da realização do ato ótimo, implica o reconhecimento da eficácia horizontal dos direitos fundamentais, em que ambos os institutos em harmonia dão azo ao princípio da juridicidade; ou seja, o princípio da juridicidade deriva da relação implicacional entre a razoabilidade qualificada e a necessidade de eficácia horizontal dos direitos fundamentais de proteção à vida e à saúde. 
(v) Todos esses fatores acima relacionados dão azo, por resultado proposicional, ao ato administrativo qualificado de proteção a direitos sociais de urgência.

Diante de todo o exposto, há de se assentar que o ato administrativo, enquanto simples ou não qualificado, sem o juízo de sopesamento de valores constitucionais sensiveis, não se norteia pela noção de necessidade de eficácia horizontal de direitos fundamentais, mormente pelo fato de se encontrar defeso ao passar ao largo de sofrer incidência do princípio da juridicidade, por mais que se possa constatar que ele atenda ao princípio da legalidade, com a manutenção da coerência interna sistêmica, em conotação com uma harmonia objetiva com o ordenamento jurídico.

Há de se constatar que as decisões na área do direito à vida e à proteção à saúde, proferidas pelo Supremo Tribunal Federal, a exemplo da expressa pela ementa que transcrevemos no item 1 alhures, ao abordarmos "a identificação de vinculação da Administração Pública a ações de políticas sociais de saúde”, possuem caráter declaratório do direito à vida e à proteção à saúde, exercitável pelo particular e, por contrapartida, caráter também declaratório do dever do Estado-administração nessa prestação, uma vez que a ratio decidendi tende a reconhecer a eficácia horizontal do direito constitucional para abarcar não o comumente constatado nessa área de eficácia, qual seja o direito civil, mas um ramo do direito público a saber: o direito administrativo, para a concreção de políticas públicas sociais. Destarte, não se trata de decisão condenatória de pagar ou fazer ou prestar alguma coisa, e sim de reconhecimento de um direito pretérito, passível de exercício imediato desde o seu nascedouro, com a material necessidade de assistência à saúde pelo particular, administrado, independentemente de judicialização da pretensão.

A efetiva gestão de políticas públicas sociais pela Administração pública impõe mais que uma mera busca de harmonia objetiva. Requer a utilização de moderna hermenêutica, para se incluir os valores sensíveis de direitos sociais ao processo de produção do ato administrativo, mormente o reconhecimento da eficácia horizontal como decorrente do princípio da juridicidade, a impor o dever de ação imediata e direta ao Estado-executivo, para a fiel concretização de preceitos e valores constitucionais.

The legality of the State in implementation public health policy - A method for justification of the effectiveness of fundamental rights

Abstract: The text seeks to demonstrate the possibility of direct use by the public authorities regardless of infra rules positivation, the constitutional status of protection, a corollary of the right to life, to the concretion of the right to health, in cases of urgency. To this end, we present to debate the legal reasoning, including formal logic inputs, to establish the contours, scope and limits of the legal state action to harmonize with the new plexus of normativity of the principle of administrative legality. The research brings a unique focus on the expansion of autonomy of administrative hermeneutics which, however, paradoxical way, leads to the obligation of completing the great administrative act, for the efficient performance of public policy management, to relieve the exhausting of the judiciary interventions and the public prosecutor, who 
would then act only post actum in cases of need caused. The methods and research techniques, from a phenomenological pre-understanding, if signed, in deduction, the literature review of domestic and foreign doctrinal texts, on the support theory and thematic analysis of Brazilian legislation.

Keywords: Right to health. Protection of life. Duty to funding by the State. Principle of administrative legality. Constitutional administrative law.

\section{Referências}

ALBUQUERQUE JÚNIOR, Raimundo Parente de. Juridicidade contra legem no processo administrativo: limites e possibilidades à luz dos postulados da razoabilidade e da proporcionalidade. Porto Alegre: Livraria do Advogado, 2010.

ALEXY, Robert. Teoría de los derechos fundamentales. Madrid: Centro de Estudios Políticos y Constitucionales, 2002.

ALVES, Alaôr Caffé. Lógica, pensamento formal e argumentação. Elementos para o discurso jurídico. 5. ed. São Paulo: Quartier Latin, 2011.

ARAÚJO, Edmir Netto de. O ilícito administrativo e seu processo. São Paulo: Revista dos Tribunais, 1994.

ÁVILA, Humberto. Teoria dos princípios: da definição à aplicação dos princípios jurídicos. 4. ed. São Paulo: Malheiros, 2005.

BACELLAR FILHO, Romeu Felipe. Processo administrativo disciplinar. 2. ed. São Paulo: Max Limonad, 2003.

BAKHTIN, Mikhail Mikhailovich. Para uma filosofia do ato responsável. 2. ed. Tradução de Valdemir Miotello e Carlos Alberto Faraco. São Carlos: Pedro \& João Editores, 2012.

BANDEIRA DE MELLO, Celso Antônio. Curso de direito administrativo. 10. ed. São Paulo: Malheiros, 1997.

BANDEIRA DE MELLO, Celso Antônio. Discricionariedade e controle jurisdicional. 2. ed. São Paulo: Malheiros, 2000.

BANDEIRA DE MELLO, Celso Antônio. Grandes temas de direito administrativo. São Paulo: Malheiros, 2009.

BANDEIRA DE MELLO, Oswaldo Aranha. Princípios gerais de direito administrativo. Rio de Janeiro: Forense, 1979. v. 1.

BANDEIRA DE MELLO, Oswaldo Aranha. Princípios gerais de direito administrativo. Rio de Janeiro: Forense, 1979. v. 2.

BARROSO, Luís Roberto. Interpretação e aplicação da Constituição. 6. ed. São Paulo: Saraiva, 2004.

BARROSO, Luís Roberto. O direito constitucional e a efetividade de suas normas. Rio de Janeiro: Renovar, 2002.

BITENCOURT, Carolina Müller. Controle jurisdicional de políticas públicas. Porto Alegre: Núria Fabris, 2013.

BITTAR, Eduardo C. B. Linguagem jurídica. 2. ed. São Paulo: Saraiva, 2006.

BOBBIO, Norberto. A era dos direitos. Tradução de Carlos Nelson Coutinho. Rio de Janeiro: Elsevier, 2004. 
BOBBIO, Norberto. Teoria da norma jurídica. 2. ed. São Paulo: Edipro, 2003.

BOBBIO, Norberto. Teoria do ordenamento jurídico. 10. ed. Brasília: Universidade de Brasília, 1999. BONAVIDES, Paulo. Curso de direito constitucional. 28. ed. São Paulo: Malheiros, 2013.

BRASIL JÚNIOR, Samuel Meira. Precedentes vinculantes e jurisprudência dominante na solução das controvérsias. Tese (Doutorado) - Faculdade de Direito, Universidade de São Paulo, São Paulo, 2010.

CAETANO, Marcello. Manual de direito administrativo. Coimbra: Coimbra Editora, 1951.

CAETANO, Marcello. Manual de direito administrativo. Introdução, organização administrativa, atos e contratos administrativos. Rio de Janeiro: Forense, 1970. t. I.

CAETANO, Marcello. Princípios fundamentais do direito administrativo. Rio de Janeiro: Forense, 1977.

CANOTILHO, José Joaquim Gomes. Constituição dirigente e vinculação do legislador. Coimbra: Coimbra Editora, 1994.

CANOTILHO, José Joaquim Gomes. Direito constitucional e teoria da Constituição. 7. ed. Coimbra: Almedina, 2003.

CASTRO, Carlos Roberto Siqueira. A Constituição aberta e os direitos fundamentais. Ensaios sobre o constitucionalismo pós-moderno e comunitário. Rio de Janeiro: Forense, 2003.

CASTRO, Carlos Roberto Siqueira. O devido processo legal e a razoabilidade das leis na nova Constituição do Brasil. 2. ed. Rio de Janeiro: Forense, 1989.

COELHO, Fábio Ulhôa. Roteiro de lógica jurídica. São Paulo: Max Limonad, 1996.

COELHO, Helena Beatriz Cesarino Mendes. Políticas públicas: possibilidade de controle de juridicidade a partir da vinculação às normas constitucionais. 2008. Dissertação (Mestrado em Direito) - Pontifícia Universidade Católica do Rio Grande do Sul, Porto Alegre, 2008.

CRETELLA JÚNIOR, José. Direito administrativo do Brasil. Atos e contratos administrativos. São Paulo: Revista dos Tribunais, 1961. v. III.

CRETELLA JÚNIOR, José. Tratado de direito administrativo: processo administrativo. São Paulo: Forense, 1968. v. VI.

DURKHEIM, Émile. Sociologia e filosofia. Tradução de Fernando Dias Andrade. São Paulo: Martin Claret, 2009.

DWORKIN, Ronald. Levando os direitos a sério. São Paulo: Martins Fontes, 2010.

FAGUNDES, Miguel Seabra. Voto relator na apelação cível № 1.422. Revista de Direito Administrativo, São Paulo, v. 14, 1948.

FERRAZ JUNIOR, Tercio Sampaio. Introdução ao estudo do direito: técnica, decisão, dominação. 4. ed. São Paulo: Atlas, 2003.

FRANCO, Afonso Arinos de Melo. Curso e direito constitucional brasileiro. Teoria geral. Rio de Janeiro: Forense, 1968. v. I.

GARCIA DE ENTERRÍA, Eduardo. Reflexiones sobre la ley y los principios generales del derecho. Madrid: Civitas, 1996.

GRAU, Eros Roberto. O direito posto e o direito pressuposto. São Paulo: Malheiros, 2008.

HAARSCHER, Guy. A filosofia dos direitos do homem. Lisboa: Instituto Piaget, 2007.

HART, Herbert L. A. El concepto de derecho. Traducción de Genaro R. Carrió. Buenos Aires: AbeledoPerrot, 1963. 
HAURIOU, André. A utilização em direito administrativo das regras e princípios do direito privado. Revista de Direito Administrativo, v. I, n. 2, tradução de Paulo da Mata Machado, 1945.

HAURIOU, Maurice. Précis de droit administratif et de droit public. Paris: Recueil Sirey, 1933.

HORBACH, Carlos Bastide. Direito administrativo e privado na obra de Ruy Cirne Lima. Belo Horizonte: Fórum, 2009.

HORBACH, Carlos Bastide. Teoria das nulidades do ato administrativo. 2. ed. São Paulo: Revista dos Tribunais, 2010.

HOTTOIS, Gilbert. Pensar a lógica. Uma introdução técnica e teórica à filosofia da lógica e da linguagem. Tradução de Miguel Mascarenhas. Lisboa: Instituto Piaget, 2004.

KELSEN, Hans. Teoria pura do direito. Tradução de João Batista Machado. São Paulo: Martins Fontes, 1999.

LANGER, Susanne K. An introduction to symbolic logic. Boston: Houghton Miffelin Company, 1937.

LEAL, Vítor Nunes. Poder discricionário e ação arbitrária da Administração. São Paulo: Fundação Carlos Chagas, 1948. v. 14.

LIMA, Ruy Cirne. Princípios de direito administrativo. São Paulo: Malheiros, 2007.

LUHMANN, Niklas. Sistema juridico y dogmatica juridica. Madrid: Centro de Estudios Constitucionales, 1974.

MARTARI, Cezar A. Introdução à lógica. São Paulo: Unesp, 2001.

MAURER, Hartmut. Direito administrativo geral. 14. ed. Tradução de Luiz Afonso Heck. São Paulo: Manole, 2006.

MAXIMILIANO, Carlos. Hermenêutica e aplicação do direito. 4. ed. São Paulo: Freitas Bastos, 1947. MAYER, Otto. Derecho administrativo alemán. Parte Geral. Traducción de Horacio H. Heredia y Ernesto Krotoschin. Buenos Aires: Editorial Depalma, 1949. t. I.

MEDAUAR, Odete. A processualidade no direito administrativo. 2. ed. São Paulo: Revista dos Tribunais, 2008.

MEIRELLES. Hely Lopes. Direito administrativo brasileiro. 24. ed. São Paulo: Malheiros, 1999.

PERELMAN, Chaïm. Le champ de l'argumentation. Bruxelles: Presses Universitaires de Bruxelles, 1970.

PERELMAN, Chaïm. Lógica jurídica: nova retórica. São Paulo: Martins Fontes, 2004.

PRADO JÚNIOR, Caio. Introdução à lógica dialética: notas introdutórias. 4. ed. São Paulo: Brasiliense, 1979.

RAMOS, Elival Silva. Ativismo judicial. Parâmetros dogmáticos. São Paulo: Saraiva, 2010.

ROUSSEAU, Jean-Jacques. Do contrato social. Princípios do direito político. 2. ed. São Paulo: Revista dos Tribunais, 2010.

SIQUEIRA, Galdino. Tratado de direito penal. Parte geral. Rio de Janeiro: José Konfino Editor, 1947. t. I. STRAUSS, Leo. Direito natural e história. Lisboa: Edições 70, 2009.

STRECK, Lenio Luiz. Prefácio. In: LUIZ, Fernando Vieira. Teoria da decisão judicial: dos paradigmas de Ricardo Lorenzetti à resposta adequada à Constituição de Lenio Streck. Porto Alegre: Livraria dos Advogados, 2013.

SUPIOT, Alain. Homo juridicus: ensaios sobre a função antropológica do direito. São Paulo: Martins Fontes, 2007. 
TORRINHA, Francisco. Dicionário latino português. Porto: Práticas Reunidas Ltda., 1942.

VARELLA, Marcelo Dias. Direito internacional público. 4. ed. São Paulo: Saraiva, 2013.

VIGO, Rodolfo Luis. Interpretação jurídica. Do modelo juspositivista-legalista do século XIX às novas perspectivas. 2. ed. Tradução de Suzana Helena Dalle Mura. São Paulo: Revista dos Tribunais, 2010.

VILANOVA, Lourival. Escritos jurídicos e filosóficos. 1. ed. São Paulo: Ibest, 2003. v. 1.

VILANOVA, Lourival. Escritos jurídicos e filosóficos. 1. ed. São Paulo: Ibest, 2003. v. 2.

VON IHEING, R. Espiritu del derecho romano em las diversa etapas de su desarrollo. La dogmática jurídica. Buenos Aires: Losada, 1946.

WEINREB, Lloyd L. A razão jurídica. 0 uso da analogia no argumento jurídico. São Paulo: Martins Fontes, 2008.

WRÓBLEWSKI, Jerzy. Justificación de las decisones jurídicas. In: WRÓBLEWSKI, Jerzy. Constitución y teoria general de la interpretación jurídica. Traducción de Arantxa Azurza. Madrid: Civitas, 1985.

Informação bibliográfica deste texto, conforme a NBR 6023:2002 da Associação Brasileira de Normas Técnicas (ABNT):

DEZAN, Sandro Lucio; BRASIL JÚNIOR, Samuel Meira. A juridicidade do Estadoadministração na concretização de políticas públicas de saúde - Um método para a justificação da eficácia horizontal dos direitos fundamentais. A\&C - Revista de Direito Administrativo \& Constitucional, Belo Horizonte, ano 16, n. 63, p. 211-238, jan./mar. 2016.

Recebido em: 06.03.2015

Aprovado em: 02.05.2015 